\title{
High prevalence of anomalies in Nyctimantis brunoi (Anura: Hylidae) from a restinga protected area in southeastern Brazil
}

\author{
Luiz Fernando Carmo, ${ }^{1}$ Suellen de Oliveira Guimarães, ${ }^{1}$ Ingrid Ribeiro Miguel, ${ }^{1}$ Pedro H. \\ Pinna, ${ }^{1,2}$ Daniel Silva Fernandes, ${ }^{2}$ and Manoela Woitovicz-Cardoso ${ }^{1}$ \\ ${ }^{1}$ Universidade Federal do Rio de Janeiro, Museu Nacional, Departamento de Vertebrados. Quinta da Boa Vista, 20940-040, \\ Rio de Janeiro, RJ, Brazil. E-mail: luiz.carmo@ufrj.br. \\ ${ }^{2}$ Universidade Federal do Rio de Janeiro, Instituto de Biologia, Departamento de Zoologia. Ilha do Fundão, 21941-902, Rio de \\ Janeiro, RJ, Brazil.
}

\begin{abstract}
High prevalence of anomalies in Nyctimantis brunoi (Anura: Hylidae) from a restinga protected area in southeastern Brazil. In the present study we monitored a population of Nyctimantis brunoi, a species commonly found in restingas of southeastern Brazil. Field activities were carried out in the Parque Nacional da Restinga de Jurubatiba (PNRJ), a protected area located in the northern portion of the state of Rio de Janeiro. Specimens were sampled through a complete species inventory. We analyzed 218 individuals, 32 (14.7\%) of which have anomalies. Additionally, a subsample of 15 specimens were radiographed to verify the occurrence of skeletal anomalies not externally detectable and to verify if the classification of anomalies attributed by means of external examination are detectable in the osteological structure of the specimen. There are 12 types of anomalies recognized in this population, three of them only detectable through internal investigation (radiography). We verified that most of anomalies externally detectable were correctly classified when compared to the osteological morphology of the radiographed specimens. Thus, in this investigation, the study of external malformations was capable to detect $60 \%$ of the types of anomalies. We conclude that further ecotoxicological and epidemiological studies of the population of $N$. brunoi in the PNRJ are necessary to establish the origins of anomalies in this species.
\end{abstract}

Keywords: Amphibia, bioindicators, Casque-headed treefrogs, contaminants, morphological abnormalities, skeletal deformities.

\footnotetext{
Resumo

Alta prevalência de anomalias em Nyctimantis brunoi (Anura: Hylidae) de uma área protegida de restinga do sudeste do Brasil. No presente estudo, nós monitoramos uma população de Nyctimantis brunoi, espécie comumente encontrada em restingas do sudeste do Brasil. As atividades de campo foram realizadas no Parque Nacional da Restinga de Jurubatiba (PNRJ), uma unidade de conservação federal localizada na porção norte do estado do Rio de Janeiro. Os espécimes foram
}

Received 04 October 2021

Accepted 14 December 2021

Distributed December 2021 
amostrados por meio de inventário completo de espécies. Foram analisados 218 indivíduos, dos quais $32(14,7 \%)$ apresentaram algum tipo de anomalia. Além disso, uma subamostra de 15 espécimes foi radiografada para verificar a ocorrência de anomalias esqueléticas não detectáveis externamente e para verificar se as classificações das anomalias atribuídas por meio do exame externo são detectáveis na estrutura osteológica dos espécimes. Foram encontrados 12 tipos de anomalias nesta população, sendo três delas detectáveis apenas através de imagens de radiografia. Verificamos que a maioria das anomalias detectáveis externamente foram corretamente classificadas quando comparadas à morfologia osteológica dos espécimes radiografados. Assim, nesta investigação, o estudo das malformações externas foi capaz de detectar $60 \%$ dos tipos de anomalias. Concluímos que mais estudos ecotoxicológicos e epidemiológicos da população de $N$. brunoi no PNRJ são necessários para estabelecer a origem das anomalias nessa espécie.

Palavras-chave: Amphibia, anomalias morfológicas, bioindicadores, deformidades esqueléticas, pererecas-de-capacete, contaminantes.

\section{Introduction}

The global declines of amphibians and the increasingly common records of species with abnormal features have promoted concern among researchers in the current century (Meteyer et al. 2000, Roelants et al. 2007, Hayes et al. 2010, Green et al. 2020). Morphological abnormalities in anurans have been relatively well reported to several populations worldwide (Meteyer et al. 2000, Schoff et al. 2003, Thigpen et al. 2014, Monroy-Vilchis et al. 2015, Rebouças et al. 2019). One of the most frequently reported abnormalities in amphibians is the occurrence of external malformations, mainly in the hindlimbs and fingers (Mann et al. 2009). Although some of these malformations are associated to natural conditions (Stuart et al. 2004, Ballengée and Sessions 2009, Lunde and Johnson 2012), many others have unknown causes and may be related to several factors, mostly related to recent human-caused environmental changes, such as contamination/alteration of soil and water (see Ankley et al. 2004, Lanno 2008). One of the main causes of amphibian population losses, habitat destruction, does not seem to explain declines occurring in undisturbed areas (Marco et al. 1999). An apparently suitable habitat for the stability of amphibian populations may be considerably altered, for instance, by chemical contaminants that permeate lakes, ponds and streams (Marco et al. 1999). It is known that anurans exposed to large amounts of chemicals (e.g., pesticides and fertilizers) and/or solid, liquid and suspension residues may show abnormalities, which are increasingly frequent (Miles and Pfeuffer 1997, Marco et al. 1999, Shivaramaiah et al. 2005, Moreira et al. 2012, Guerra and Aráoz 2016, Gonçalves et al. 2017, Araújo et al. 2020). Anurans have a relevant function as biological indicators of environmental conditions (Almeida et al. 2019), as they have permeable skin, unshelled eggs and often have an aquatic larval stage before metamorphosing into a terrestrial adult (Blaustein and Kiesecker 2002, Blaustein and Johnson 2003, Simon et al. 2011, Aguillón-Gutiérrez and Ramírez-Bautista 2018). Therefore, they are exposed to aquatic, atmospheric and soil stressors (Almeida et al. 2019).

Nyctimantis Boulenger, 1882 comprises seven species of Casque-headed treefrogs distributed in the Amazonian and Atlantic rainforests (Blotto et al. 2020). Nyctimantis brunoi (Miranda-Ribeiro, 1920) is the most well-known species of the genus, with several studies related to ecological issues (e.g., Trueb 1970, Andrade and Abe 1997, Teixeira et al. 2002, Mesquita et al. 2004, Wogel et al. 2006, Jared et al. 2015, Carmo and Woitovicz-Cardoso 2018, Murta-Fonseca et al. 2020). As in other species of the genus, N. brunoi has a heavily ossified skull, with cranial crests, ridges, and flanges (Trueb 1970). Such anatomical attributes were suggested as evolutionary 
adaptations to habitats with low water potential (Trueb 1970) and associated to phragmotic (e.g., using the head to plug burrows) and other defensive behaviors (Pimenta et al. 2009, Jared et al. 2015). The species is endemic to Atlantic Forest morphoclimatic domains, occurring from the state of São Paulo to the state of Bahia (Frost 2021), and is relatively common in sandy coastal environments, being one of the anuran species most frequently recorded in this ecosystem in southeastern Brazil (Rocha et al. 2008). Although the taxon is found mainly associated with bromeliads (see Teixeira et al. 2002, Mesquita et al. 2004), it uses temporary swamps and periodically flooded areas for breeding and spawning during the rainy season (Freire et al. 2019).

In the present study we reported the morphological abnormalities found in N. brunoi from Parque Nacional da Restinga de Jurubatiba, a sandy coastal environment in southeastern Brazil. Additionally, we verified if the classification of malformations externally visible are detectable in the osteological structure. We also discussed possible causes for these malformations that must be further investigated and emphasize the importance of developing plans for protecting the natural habitats of this species and other possibly threatened anurans.

\section{Materials and Methods}

\section{Study Area and Fieldwork}

We collected individuals of $N$. brunoi from August 2013 to June 2019 by means of complete species inventory (Scott and Norman 2001). We also included in our analysis specimens from PNRJ collected since 1999 (not included on the map) and deposited in the Amphibian Collection of Museu Nacional, Universidade Federal do Rio de Janeiro (MNRJ). In sandy coastal environments from southeastern Brazil, $N$. brunoi is one of the most common anuran species (Teixeira et al. 2002), being also abundant in the present study area (Carmo et al. 2019). Therefore, we choose the species as a model to assess for the first time the malformation rate in this type of habitat.

\section{Data Collection and Analysis}

We categorized adults, juveniles, males, and females based on Mesquita et al. (2004). These categorizations were made through direct observation of gonads, vocal slits, nuptial pads and snout-vent length (SVL). Morphological abnormalities detected externally were photographed in a Leica M205C stereoscope coupled to a DFC 450 camera. Additionally, a subsample of 15 specimens were radiographed to verify if the classification of externally visible malformations are detectable in the osteological structure, and to verify the occurrence of skeletal anomalies not externally noticeable. This subsample was randomly constituted, since it was not possible to radiograph all malformation individuals. As a criterion, if an anomaly was detected more than once in the same individual, it was quantified as a single case, rather than being quantified as the number of times it was detected. As all contingency tables showed values of expected frequencies greater than five, we performed chi-square tests (see Gotelli and Ellison 2011) to examine the prevalence of anomalies between juveniles and adults, males and females, and to verify if the prevalence of anomalies found in this study was similar to the threshold of $5 \%$ of naturally expected malformation proposed by Lunde and Johnson (2012). For all tests performed, a significance level of 0.05 was adopted.

Voucher specimens were collected, anesthetized and killed with lidocaine $2 \%$, fixed in formaldehyde $10 \%$, subsequently preserved in $70 \%$ ethanol [usual techniques described by McDiarmid (1994)], and deposited in the amphibian collection of MNRJ. We follow the guide to malformations of frogs and toads proposed by Meteyer (2000), Zaks (2008), Vershinin (2015), and Henle et al. (2017) with adaptations (for details, see Table 1). 


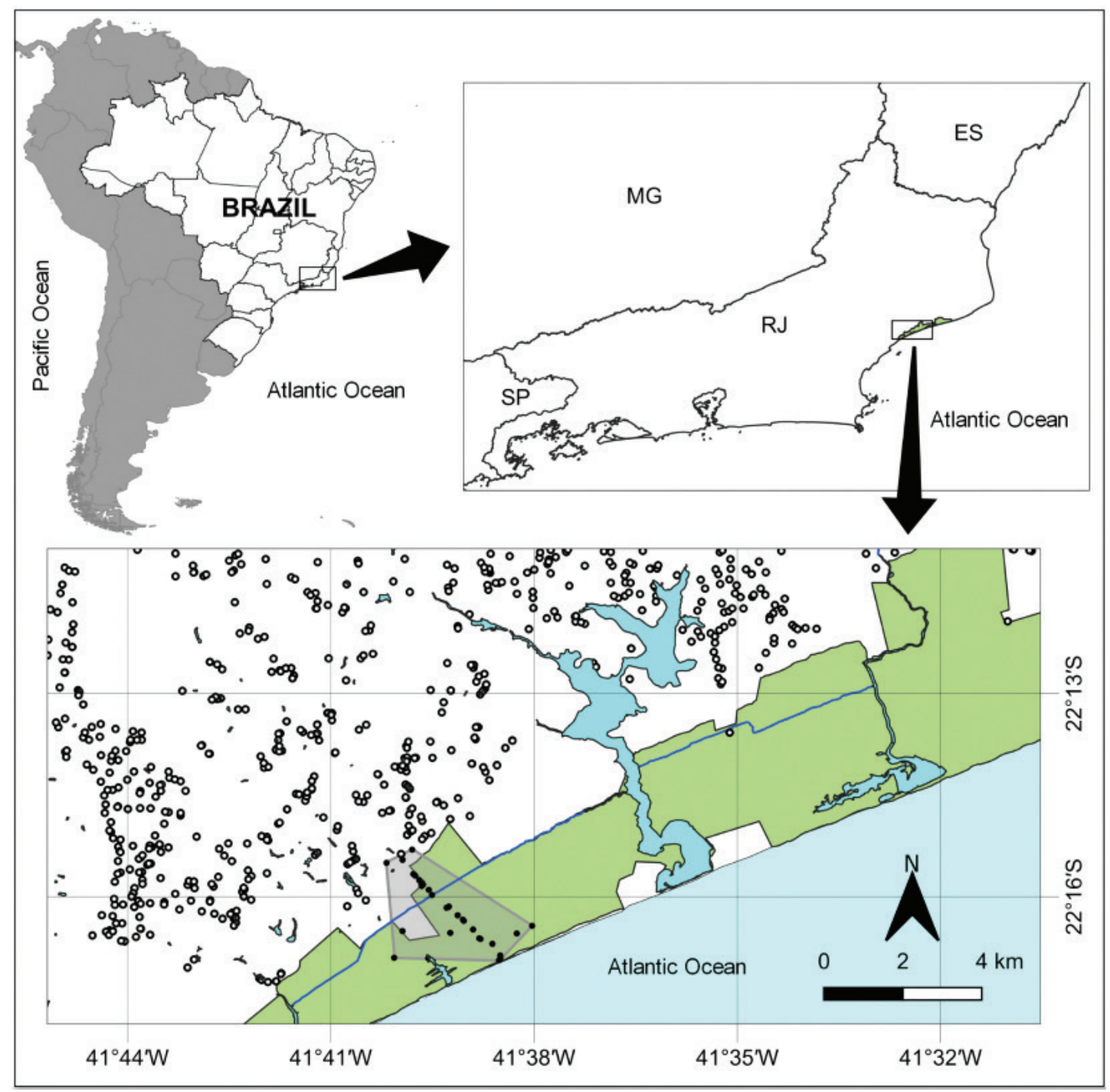

Figure 1. Map of the study area. Green: Parque Nacional da Restinga de Jurubatiba area. Black dots: surveyed start points; gray area around black dots: sample area extrapolated by wrap convex; dark blue line: CamposMacaé Channel; open circles: farms in the municipalities of Carapebus and Quissamã (IBGE 2017a), and buildings of agricultural, farming, vegetal extraction and/or fishing activities (IBGE 2018). States of São Paulo (SP), Minas Gerais (MG), Rio de Janeiro (RJ) and Espírito Santo (ES).

\section{Results}

We analysed 218 individuals of $N$. brunoi, being 142 adults (45 males and 97 females) and 73 juveniles (29 young males, 39 young females and five with sex undetermined). It was not possible to determine sex and age for three individuals in the sample.

We recorded a total of 32 malformed specimens $(14.7 \%$ of our sample): extra- 
numerical tubercle, absence of subarticular tubercle, abnormal adhesive disc, brachydactyly, microdactyly, ectrodactyly, polyphalangia, phalanx rotation, syndactyly, scoliosis, tarsalia abnormal and urostyle torsion (Table 1). Ten of the 32 malformed specimens $(4.6 \%$ of our sample; $31.3 \%$ of the malformed specimens) were affected by more than one type of anomaly (maximum of five), totaling a number of 48 malformation cases of $N$. brunoi analyzed).

All external anomalies affected the locomotors appendages, specifically the digits (45 cases of external anomalies out of 48 cases of anomalies detected $=93.8 \%$ ) (Figure 2). Among the 12 recorded types of anomalies, brachydactyly (45.8\%; $\quad N=22 \quad$ cases), microdactyly (16.7\%; $\quad N=8$ cases) and abnormal adhesive disc $(14.6 \% ; N=7$ cases $)$ were the most frequent. From the 12 types of morphological abnormalities recognized in this population, three were only detectable through internal investigation (radiography) and affected the appendicular skeleton (tarsalia abnormal) (Figure 2B) and the axial skeleton (vertebral column and urostyle) (Figure 3). Additionally, one radiographed specimen (MNRJ 66384) had an enlargement on the right tibia-fibula (Figure 3B), resembling a tumor. Since it was not possible to verify if this enlargement was really a tumor or a consolidated fracture without a histological analysis, we did not include this observation as an anomaly. For the 15 radiographed specimens (six young and nine adults), we registered 21 cases of malformations: three revealed only in the radiographs and 18 externally detected prior to radiography. From the 18 externally detectable cases of malformations, 13 were correctly classified when compared to the osteological morphology of the specimens on the radiographs; two were incorrectly classified; and three could not be confirmed, since the portion affected by the anomaly was not exposed on the radiograph. The 21 cases of malformations registered for the 15 radiographed specimens corresponded to six types of malformations, three of which were only detectable in the radiographs and three that were externally detectable. Thus, the study of external malformations alone would contribute to the detection and correct classification of $60 \%$ of the cases of anomalies and $50 \%$ of the types of anomalies we found in our subsample of $N$. brunoi.

Discriminating our sample by life stage, we detected malformations in $21(14.8 \%)$ of the 142 adults analyzed and in $11(15.1 \%)$ of the 73 juveniles. Phalanx rotation, polyphalangia, urostyle torsion, and scoliosis were found only in juveniles. Ectrodactyly, syndactyly, abnormal subarticular tubercles, and tarsalia abnormal were found only in adults. There is no difference in the prevalence of anomalies between adults and juveniles $\left(\chi^{2}=0.93 ; p=0.34\right)$, then we analyzed juveniles and adults altogether for the comparison between sexes. We detected malformations in $11(14.9 \%)$ of the 74 males analyzed and in $20(14.7 \%)$ of the 136 females. Phalanx rotation, ectrodactyly, urostyle torsion and tarsalia abnormal were found only in males, and abnormal subarticular tubercles, polyphalangy, syndactyly and scoliosis were found only in females. There is no difference in the prevalence of anomalies between sexes $\left(\chi^{2}=0.85 ; p=0.36\right)$. Thus, we considered the prevalence of the population as a whole and compared it to the threshold of 5\% of naturally expected malformation (Lunde and Johnson 2012). In the population of $N$. brunoi of PNRJ, $14.7 \%$ of the analyzed specimens have some anomaly, a prevalence that is far beyond what is naturally expected $\left(\chi^{2}=42.99 ; p<0.01\right)$.

\section{Discussion}

Our results demonstrate that the prevalence of anomalies in Nyctimantis brunoi from PNRJ is significantly higher than the expected natural rate of 5\% for amphibians (Lunde and Johnson 2012). Nyctimantis brunoi has indirect development, depending on aquatic environments to reproduce. Their eggs and exotrophic larvae are found in lentic waters (reproductive mode 1 sensu Haddad 


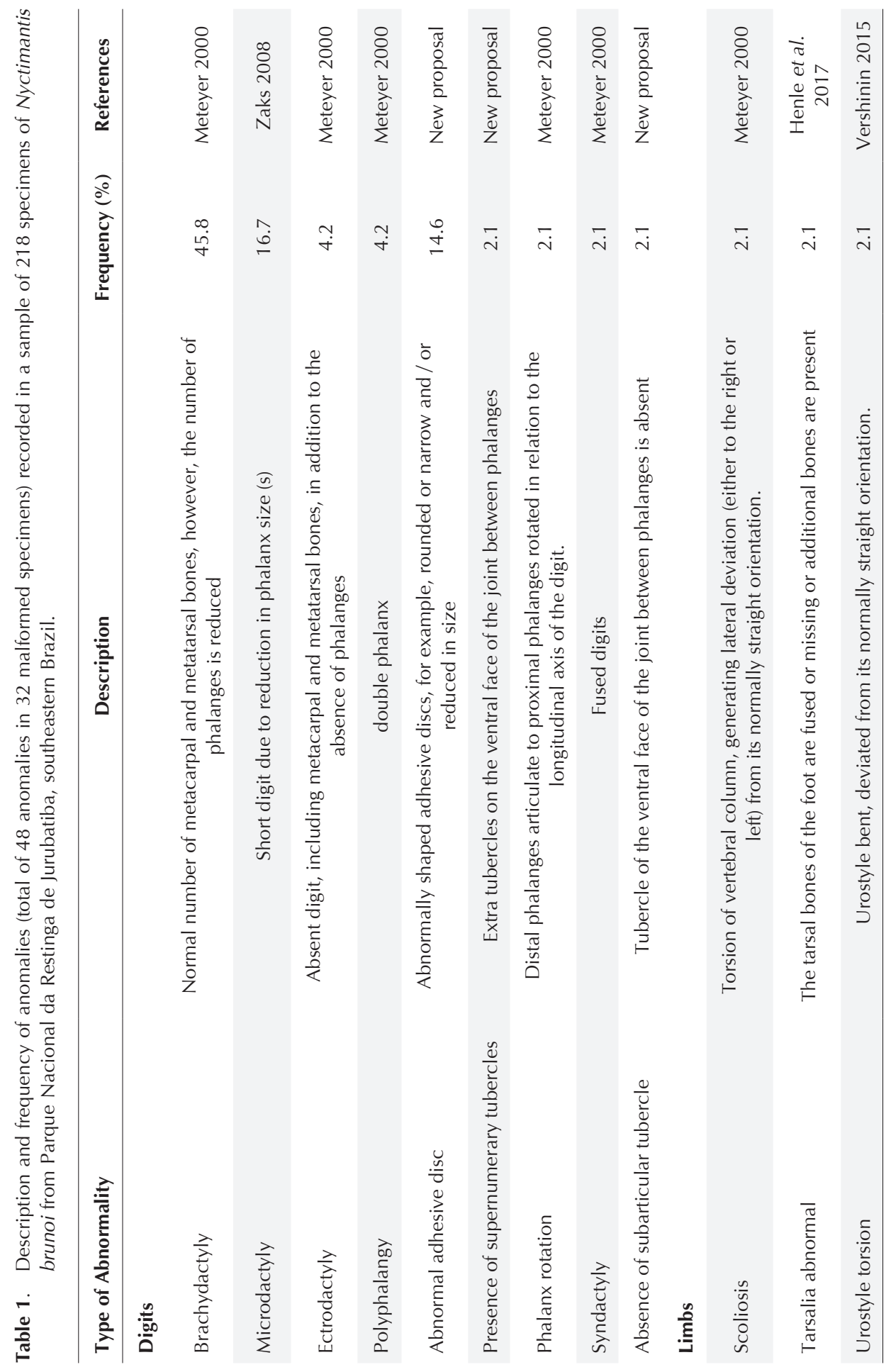



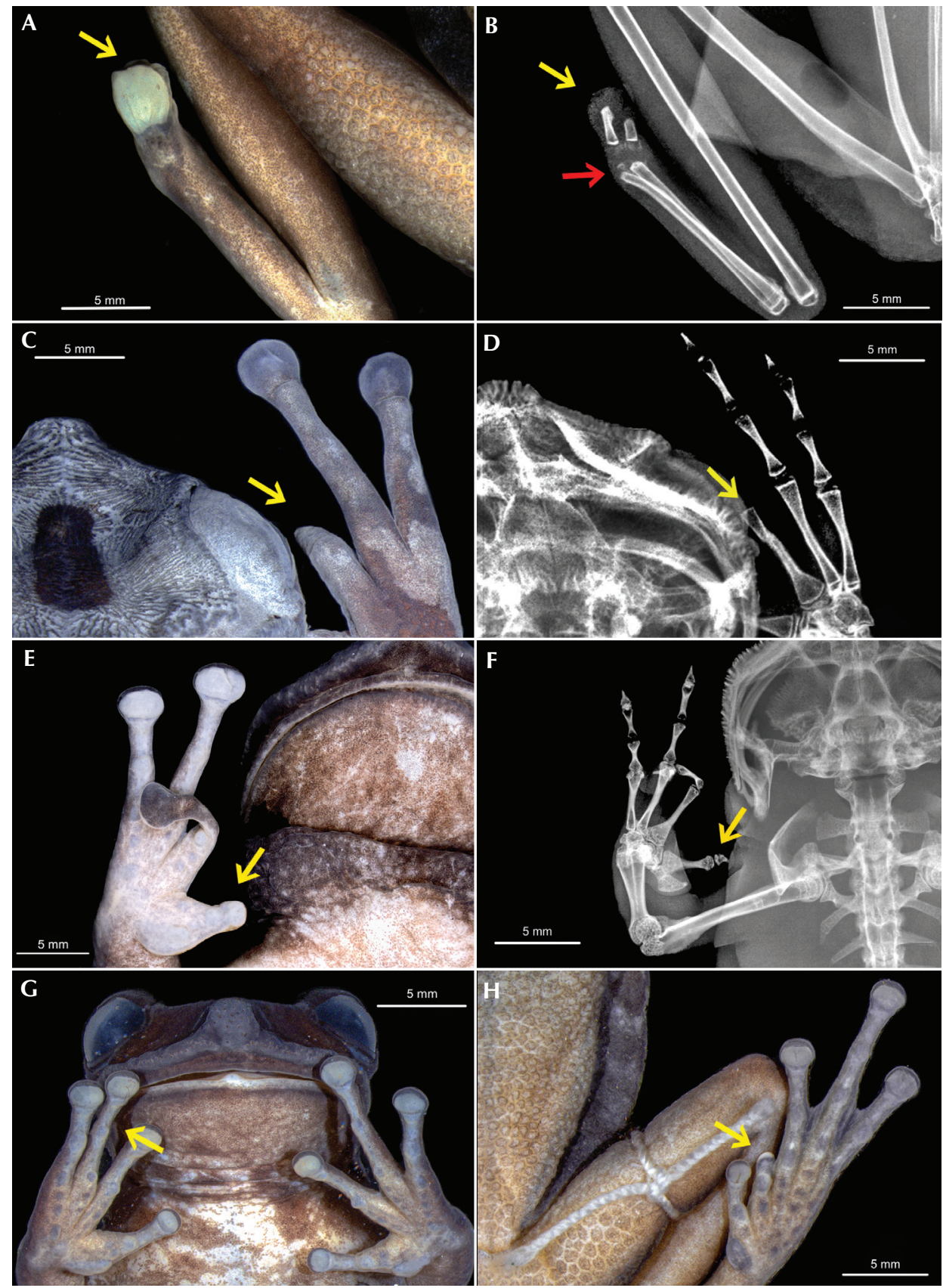

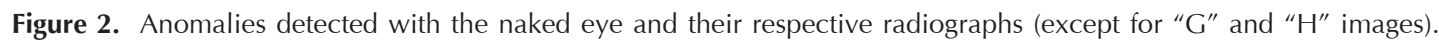
(A-B) Adult male with abnormal adhesive disc, ectrodactyly (yellow arrow) and tarsalia abnormal (red arrow) in right hindlimb (MNRJ 88014). (C-D) Adult male with brachydactyly and microdactyly in right forelimb (yellow arrow) (MNRJ 92815). (E-F) Adult male with brachydactyly in right forelimb (yellow arrow) (MNRJ 89418). (G-H) Adult female with brachydactyly in right forelimb and in left hindlimb (yellow arrow) (MNRJ 92604). 


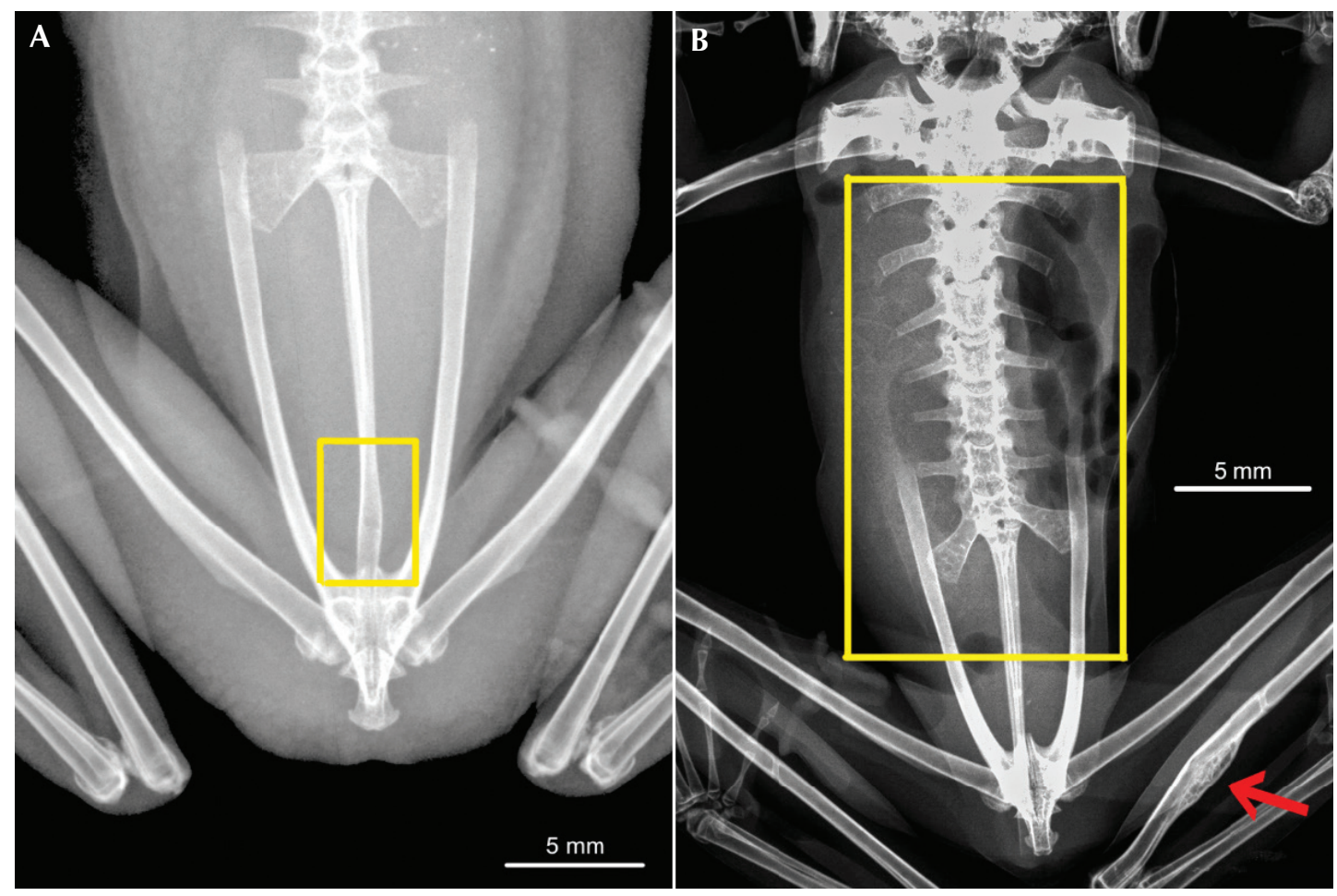

Figure 3. Anomalies in the axial skeleton detected via radiography. (A) Young male with urostyle torsion (MNRJ 92586); (B) Juvenile female with scoliosis (MNRJ 66384) and enlargement on the right tibia-fibula (red arrow).

and Prado 2005) in temporary puddles (Wogel et al. 2006). These characteristics can influence the exposure to factors that trigger anomalies, as well as their prevalence in the species (Johnson et al. 2010, Laurentino et al. 2016). Among the recorded specimens with anomalies, the most frequent type was the absence and/or reduction of the extremities of the limbs (brachydactyly, microdactyly and abnormal adhesive disc). Apparently, anomalies related to absence and/or reduction of segments are common in anurans, since it has been well reported in many other studies (e.g., Meteyer et al. 2000, Fayzulin et al. 2018, Ascoli-Morrete et al. 2019, RamírezJaramillo 2019, Rebouças et al. 2019, PedrosoSantos et al. 2020, Santana et al. 2020).

Different factors may be related to the occurrence of anomalies in amphibians and, according to previous studies, it is possible to correlate certain types of anomalies to potential causal factors. Carmona-Zamora et al. (2020) suggested that records of brachydactyly and ectrodactyly in individuals of Rheohyla miotympanum (Cope, 1963), a species that also has records of parasitoidism by flies (VázquezCorzas et al. 2018), could be related to bioaccumulation of organochlorine pesticides (see Valdespino et al. 2015). Anomalies in the autopodia (e.g., brachydactyly and ectrodactyly) have also been detected in individuals with parasitic infection by nematodes, trematodes, and a high incidence of pesticides and heavy metal residues in body tissues (Linzey et al. 2003). In addition, reductions in the autopodia were also detected in individuals sampled in highly industrialized regions, with rates of 
anomalies being higher in species associated with water bodies (Flyaks and Borkin 2004). Besides the brachydactyly and ectrodactyly, other anomalies recorded here have been detected in individuals from agricultural areas in other studies, such as polyphalangia and syndactyly (Ouellet et al. 1997, Peltzer et al. 2011, Moreira et al. 2012, Agostini et al. 2013, Ascoli-Morrete et al. 2019, Ferrante and Fearnside 2020), which may be related to the exposure to chemical contaminants. A recessive and semi-lethal mutation denominated $\mathrm{M}_{5}$, which affects the tadpoles of Xenopus laevis (Daudin, 1802), has been shown to be involved in the appearance of some anomalies (Droin and Fischberg 1980), including brachydactyly, syndactyly and ectrodactyly, which were also recorded in our sample. The PNRJ is surrounded by small farms of livestock and crops and the study site is located at the municipality of Carapebus (Figure 1). According to the federal census, this municipality has 549 farms, of which only 20 used pesticides and more than 350 applied fertilizers (IBGE 2017b). Since this data are auto declaratory and not restricted to the neighbouring areas of the PNRJ, we do not have data to relate the occurrence of pesticides and fertilizers with the high prevalence of abnormalities observed in the population of Nyctimantis brunoi.

Sub-lethal predation can also explain anomalies involving the absence and/or reduction of limbs and limb segments (Ballengée and Sessions 2009). Such anomalies may represent normal regenerative responses to the injuries caused by predation attempts (Ballengée and Sessions 2009), due to the regenerative capacity of the amphibians (Kollros 1984). The greater the stage of development in anurans, the greater the possibilities of incomplete regeneration due to the ontogenetic decline in regenerative capacity (Ballengée and Sessions 2009). Based on field observations and available literature, macroinvertebrates such as Hirudinea, Arachnida, Coleoptera (Dytiscidae), Odonata, and Hemiptera, are the main sub-lethal predators of the anuran larvae (França and Callisto 2007, Gambale et al. 2014), and a great variety of them occur in the PNRJ. Temporary water bodies harbor smaller abundance of predators than permanent water bodies (Santos et al. 2007). Although $N$. brunoi uses mostly temporary ponds for reproduction, we observed individuals in reproductive activity in semi-permanent lentic water bodies in the PNRJ. Our data is not conclusive about the occurrence of sub-lethal predation on early stages in $N$. brunoi as a cause of anomalies. However, the similar prevalence of anomalies between juveniles and adults may indicate that there is no anomaly caused by sublethal predation in adult specimens. So, if there is sub-lethal predation on N. brunoi, it occurs in the early stages of life.

In addition to the potential causes aforementioned, UV-B radiation, viral infections, infection caused by the trematodes Ribeiroia ondatrae (Price, 1931) Price, 1942, Acanthostomum burminis (Bhalerao, 1926) Bhalerao, 1936, and Strigea robusta (Szidat, 1928), and parasitic copepod invasion [Lernaea cyprinacea (Linnaeus, 1758)] are also associated with developing of limb malformations in amphibians (Stocum 2000, Blaustein and Johnson 2003, Johnson et al. 2004, Burton et al. 2008, Rajakaruna et al. 2008, Kupferberg et al. 2009, Svinin et al. 2020).

Anomalies in the limbs can affect species of arboreal habit more severely than species of terrestrial or semi-aquatic habits (Agostini et al. 2013). Nyctimantis brunoi belongs to the Hylidae family (Blotto et al. 2020), which is known to encompass arboreal species, which spend most of their time perched (Almendáriz et al. 2014). As hylid frogs depend heavily on limbs and digits to climb, malformed individuals may have their activities related to arboreal habit compromised. Despite being potentially negative, the anomalies occur at a similar prevalence between juveniles and adults, indicating they are probably not affecting survival.

The expected natural rate of anomalies (5\%) adopted was proposed based only on studies 
from temperate amphibian populations (Lunde and Johnson 2012) and maybe not apply properly to Neotropical amphibians. However, the high prevalence of anomalies found at PNRJ (almost three times higher than the threshold naturally expected) brings a warning sign that something could be negatively impacting this population of $N$. brunoi. Therefore, we encourage more studies on abnormalities in Neotropical amphibians, which may shed light on the relevance of the 5\% threshold in populations other than those of temperate environments.

Although we have no evidences on the causes of the high prevalence of anomalies observed in the $N$. brunoi from PNRJ, we must consider chemical pollution. These insights are useful for a better understanding of the potential causal factors that should be investigated. The PNRJ is crossed by the Canal Campos-Macaé (Figure 1), an artificial channel that receives effluents and agrochemicals from various urban and agricultural regions along its route outside the park (ICMBio 2020b). Indirectly, the Canal Campos-Macaé can act as a carrier of pollutants and residual substances from agricultural activities into the park, since it crosses several agricultural regions (Silva et al. 2012). In addition, chemical compounds from agricultural areas close to the limits of the PNRJ can be transported through leaching and surface carrying, tending to result in contamination of groundwater and favoring contamination of surface water, respectively (Spadotto et al. 2004). Transport through volatilization and loss to neighboring areas by drift can also occur with some pesticides (Spadotto et al. 2004). Thus, amphibians that inhabit close to agricultural areas are subject to exposure to different concentrations of chemical pollutants and the effects of such substances in the wildlife are not yet fully understood (Mann et al. 2009, Gonçalves et al. 2019). Thereby, interactions between anurans and environmental stressors can affect species at the population level and, although a single stressor may not be sufficient to generate damage, multiple stressors can be extremely severe, since amphibians are susceptible to exposure to various abiotic agents (Blaustein and Kiesecker 2002).

Here, we suggest that $N$. brunoi is a relevant bioindicator species for studies of environmental biomonitoring in sandy coastal environments, since it is a species commonly found in this ecosystem and uses aquatic environments for oviposition. In conclusion, ecotoxicological and epidemiological studies of $N$. brunoi from the Parque Nacional da Restinga de Jurubatiba are necessary to establish the causes of abnormalities in this population. It is essential to expand the knowledge about the several factors that can influence the environmental quality of a region, especially concerning protected areas and how they can be affected by urban or agricultural surrounding areas. The monitoring of these areas is essential to recognize external factors which can affect the biodiversity, and to develop mitigation measures to reduce the impacts.

\section{Acknowledgments}

This study was conducted by program Pesquisas Ecológicas de Longa Duração (PELD): Mudanças Climáticas Globais e o Funcionamento dos Ecossistemas Costeiros da Bacia de Campos: uma perspectiva espaçotemporal (Brazilian Long Term Ecological Research: Global Climate Change and the Functioning of Coastal Ecosystems in the Bacia de Campos: A Space-time Perspective), initiated in August 2013 and subsidized by Conselho Nacional de Desenvolvimento Científico e Tecnológico (CNPq; processes 403841/2012-7, 441610/2016-1 and 441927/2020-3). In addition, it also integrates the program Levantamento e Aspectos Biológicos da Herpetofauna do Parque Nacional da Restinga de Jurubatiba, RJ, Brasil, supported by Fundação Carlos Chagas Filho de Amparo à Pesquisa do Estado do Rio de Janeiro (FAPERJ; process E-26/111.217/2014). LFC (132763/2020-6) and DSF was were supported by CNPq. SOG and IRM were supported by Coordenação de Aperfeiçoamento de Pessoal de 
Nível Superior - Brasil (CAPES). MWC and PHP are grateful for the fellowships E-26/200.111/2019 and E-26/200.104/2019, supported by FAPERJ. Three anonymous reviewers substantially enhanced the quality of the manuscript. We are grateful to all staff of the Instituto de Biodiversidade e Sustentabilidade (NUPEM/UFRJ), of the Parque Nacional da Restinga de Jurubatiba (PNRJ), and Museu Nacional, Universidade Federal do Rio de Janeiro for logistical support and incentive during the campaigns. The specimens were collected under permit \#38378-11, granted by the Instituto Chico Mendes de Conservação da Biodiversidade (ICMBio).

\section{References}

Agostini M. G., F. Kacoliris, P. Demetrio, G. S. Natale, C. Bonetto, and A. Ronco. 2013. Abnormalities in amphibian populations inhabiting agroecosystems in northeastern Buenos Aires Province, Argentina. Diseases of Aquatics Organisms 104: 163-171.

Aguillón-Gutiérrez D. and A. Ramírez-Bautista. 2018. Spectrochemical analysis of tissues of frog Dryophytes plicatus tadpoles (Amphibia: Hylidae) developing under lead and iron pollution. Journal of Environmental Management 21: 74-81.

Almeida P. R., M. V. Rodrigues, and A. M. Imperador. 2019. Toxicidade aguda (LC50) e efeitos comportamentais e morfológicos de formulado comercial com princípio ativo glifosato em girinos de Physalaemus cuvieri (Anura, Leptodactylidae) e Rhinella icterica (Anura, Bufonidae). Engenharia Sanitária e Ambiental 24: $1115-1125$.

Almendáriz A., J. Brito, D. Batallas, and S. Ron. 2014. Una especie nueva de rana arbórea del género Hyloscirtus (Amphibia: Anura: Hylidae) de la Cordillera del Cóndor. Papéis Avulsos de Zoologia 54: 33-49.

Andrade D. V. and A. S. Abe. 1997. Evaporative water loss and oxygen uptake in two casque-headed tree frogs, Aparasphenodon brunoi and Corythomantis greeningi (Anura, Hylidae). Comparative Biochemistry Physiology 118: 685-689.

Ankley G. T., S. J. Degitz, S. A. Diamond, and J. E. Tietge. 2004. Assessment of environmental stressors potentially responsible for malformations in North American anuran amphibians. Ecotoxicology and Environmental Safety 58: $7-16$
Araújo A. P. C., N. F. S. Melo, A. G. O. Junior, F. P. Rodrigues, T. Fernandes, J. E. A. Vieira, T. L. Rocha, and G. Malafaia. 2020. How much are microplastics harmful to the health of amphibians? A study with pristine polyethylene microplastics and Physalaemus cuvieri. Journal of Hazardous Materials 382: 121066.

Ascoli-Morrete T., E. Signor, M. Santos-Pereira, and N. Zanella. 2019. Morphological abnormalities in anurans from southern Brazil. Austral Ecology 44: 1025-1029.

Assumpção J. and M. T. Nascimento. 2000. Estrutura e composição floristica de quatro formações vegetais de restinga no complexo lagunar Grussai/Iquipari, São João da Barra, RJ, Brasil. Acta Botanica Brasilica 14: $301-$ 315 .

Ballengée B. and S. K. Sessions. 2009. Explanation for missing limbs in deformed amphibians. Journal of Experimental Zoology (Molecular and Developmental Evolution) 312B: 770-779.

Blaustein A. and P. T. J. Johnson. 2003. The complexity of deformed amphibians. Frontiers in Ecology and the Environment 1: 87-94.

Blaustein A. R. and J. M. Kiesecker. 2002. Complexity in conservation: lessons the global decline of amphibian populations. Ecology Letters 5: 597-608.

Blotto B. L., M. L. Lyra, M. C. S. Cardoso, M. T. Rodrigues, I. R. Dias, R. E. Marciano-J., F. D. Vechio, V. G. D. Orrico, R. A. Brandão, C. L. Assis, A. S. F LantyerSilva, M. G. Rutherford, G. Gagliardi-Urrutia, M. Solé, D. Baldo, I. Nunes, R. Cajade, A. Torres, T. Grant, K-H. Jungfer, H. R. Silva, C. F. B. Haddad, and J. Faivovich. 2020. The phylogeny of the Casque-headed Treefrogs (Hylidae: Hylinae: Lophyohylini). Cladistics. 37: 3672.

Brasil. 2000. Lei n ${ }^{\circ} 9.985$, de 18 de julho de 2000. Presidência da República - Casa Civil- Subchefia para Assuntos Jurídicos. 18 de julho de 2000. Available in: http:// www.planalto.gov.br/ccivil_03/leis/19985.htm. Captured on 27 April 2021.

Burton E. C., D. L. Miller, E. L. Steyer, and Gray, M. J. 2008. Amphibian ocular malformation associated with frog virus 3. Veterinary Journal 177: 442-444.

Carmo L. F., I. R. Miguel, P. H. Pinna, D. S. Fernandes, and M. Woitovicz-Cardoso. 2019. Amphibians of the Parque Nacional da Restinga de Jurubatiba, a sandy coastal environment in southeastern Brazil. Biota Neotropica 19: e20190727.

Carmo L. F. and M.Woitovicz-Cardoso. 2018. Spoiling friendship: First report on predation of anuran by Aparasphenodon brunoi Miranda-Ribeiro, 1920 (Anura: Hylidae). Herpetology Notes 11: 375-377. 
Carmona-Zamora T., A. Sandoval-Comte, and J. M. DíazGarcía. 2020. Registro de ectrodactilia y braquidactilia em Rheohyla miotympanum (Anura: Hylidae) em um cafetal bajo sombra del centro de Veracruz, México. Revista Latinoamericana de Herpetología 3: 107-110.

Cogliatti-Carvalho L., A. F. Nunes de Freitas, C. F. D. Rocha, and M. Van Sluys. 2001. Variação na estrutura e na composição de Bromeliaceae em cinco zonas de restinga no Parque Nacional da Restinga de Jurubatiba, Macaé, RJ. Revista Brasileira de Botânica 24: 1-9.

Droin A. and M. Fischberg. 1980. Abnormal limbs (abl), a recessive mutation affecting the tadpoles of Xenopus $l$. laevis. Experientia 36: 1286-1288.

Fayzulin A. L., A. K. Chikhlyaev, A. E. Mineev, R. A. Kuzovenko, F. F. Mihaylov, A. I. Zaripova, and O. A. Popov Ermakov. 2018. New data on the anomalies of tailless amphibians of the Volga Basin. KnE Life Sciences 4: 29-35.

Ferrante L. and P. M. Fearnside. 2020. Evidence of mutagenic and lethal effects of herbicides on Amazonian frogs. Acta Amazonica 50: 363-366.

Flyaks N. and L. Borkin. 2004. Morphological abnormalities and heavy metal concentrations in anurans of contaminated areas, eastern Ukraine. Applied Herpetology 1: 229-264.

França J. S. and M. Callisto. 2007. Coleção de macroinvertebrados bentônicos: ferramenta para o conhecimento da biodiversidade em ecossistemas aquáticos continentais. Neotropical Biology and Conservation 2: 3-10.

Freire I. R., H. Thomassen, P. C. Rocha, and F. S. F. Leite. 2019. Almost a hundred years later, the advertisement call of Aparasphenodon brunoi Miranda-Ribeiro 1920 (Anura: Hylidae) from the Atlantic Forest. Zootaxa 4550: 423-430.

Frost D. R. 2021. Amphibian Species of the World: an Online Reference. Version 6.1. American Museum of Natural History, New York, USA. Eletronic Database accessible at http://research.amnh.org/vz/herpetology/ amphibia/. Captured on 22 January 2021.

Gambale P. G., V. G. Batista, F. H. Oda, R. M. Campos, R. M. Takemoto, and R. P. Bastos. 2014. Anuran larvae as prey and hosts of invertebrates in neotropical aquatic habitats. Revista Chilena de Historia Natural 87: 1-5.

Gonçalves M. W., C. B. M. Campos, F. R. Godoy, P. G. Gambale, H. F. Nunes, F. Nomura, R. P. Bastos, A. D. Cruz, and D. M. Silva. 2019. Assessing genotoxicity and mutagenicity of three common amphibian species inhabiting agroecosystem environment. Archives of
Environmental Contamination and Toxicology 77: 409420.

Gonçalves M. W., P. G. Gambale, F. R. Godoy, A. A. Alves, P. H. A. Rezende, A. D. Cruz, N. M. Maciel, F. Nomura, R. P. Bastos, P. Marco-Jr., and D. M. Silva. 2017. The agricultural impact of pesticides on Physalaemus cuvieri tadpoles (Amphibia: Anura) ascertained by comet assay. Zoologia 34: 1-8.

Gotelli N. J. and A. M. Ellison. 2011. Princípios de Estatística em Ecologia. Porto Alegre. Artmed. 528pp.

Green D. M., M. J. Lannoo, D. Lesbarrères, and E. Muths. 2020. Amphibian population declines: 30 years of progress in confronting a complex problem. Herpetologica 76: 97-100.

Guerra C. and E. Araóz. 2016. Amphibian malformations and body condition across an agricultural landscape of northwest Argentina. Diseases of Aquatic Organisms 121: $105-116$.

Haddad C. F. B. and C. P. A. Prado. 2005. Reproductive modes in frogs and their unexpected diversity in the Atlantic Forest of Brazil. BioScience 55: 207-217.

Hayes T. B., P. Falso, S. Gallipeau, and M. Stice. 2010. The cause of global amphibian declines: a developmental endocrinologist's perspective. Journal of Experimental Biology 213: 921-933.

Henle K., A. Dubois, and V. Vershinin. 2017. Commented glossary, terminology and synonymies of anomalies in natural populations of amphibians. In K. Henle and A. Dubois. Studies on anomalies in natural populations of amphibians. Mertensiella 25: 9-48.

Henriques R. P. B., D. S. D. Araújo, and J. D. Hay. 1986. Descrição e classificação dos tipos de vegetação da restinga de Carapebus, Rio de Janeiro. Revista Brasileira de Botânica 9: 173-189.

IBGE - Instituto Brasileiro de Geografia e Estatística. 2017a. Rio de Janeiro. Censo Agropecuário 2017. Available in: https://www.ibge.gov.br/estatisticas/economicas/ agricultura-e-pecuaria/21814-2017-censo-agropecuario. html?=andt=downloads. Captured on 23 April 2021.

IBGE - Instituto Brasileiro de Geografia e Estatística. 2017b. 33 Rio de Janeiro. Censo Agropecuário 2017. Available in: https://cidades.ibge.gov.br/brasil/rj/carapebus/ pesquisa/24/76693. Captured on 02 July 2021.

IBGE - Instituto Brasileiro de Geografia e Estatística. 2018. BC25_RJ - Edificação agropecuária, de extrativismo vegetal ou de pesca. Base cartográfica vetorial contínua do Estado do Rio de Janeiro na escala 1:25.000 (BC25_ RJ). Rio de Janeiro: Diretoria de Geociências (DGC) / Coordenação de Cartografia (CCAR). Available 
in: https://geoftp.ibge.gov.br/cartas_e_mapas/bases_ cartograficas_continuas/bc25/rj/versao2018/ geopackage/. Captured on 23 April 2021.

ICMBio - Instituto Chico Mendes de Conservação da Biodiversidade. 2020a Parque Nacional de Jurubatiba PARNA Jurubatiba. Available in: https://www.icmbio. gov.br/parnajurubatiba/. Captured on 18 September 2020.

ICMBio - Instituto Chico Mendes de Conservação da Biodiversidade. 2020b. Plano de manejo PARNA da Restinga de Jurubatiba. Available in: https://www. icmbio.gov.br/portal/component/content/ article $? i d=2260$ : parna-da-restinga-de-jurubatiba. Captured on 20 September 2020.

Jared C., P. L. Mailho-Fontana, M. M. Antoniazzi, V. A. Mendes, K. C. Barbaro, M. T. Rodrigues, and E. D. Jr. Brodie. 2015. Venomous frogs use heads as weapons. Current Biology 25: 2166-2170.

Johnson P. T. J., M. K. Reeves, S. K. Krest, and A. E. Pinkney. 2010. A decade of deformities: advances in our understanding of amphibian malformations and their implications. Pp. 511-540 in D. W. Sparling, G. Linder, C. A. Bishop, and S. K. Krest (eds.), Ecotoxicology of Amphibians and Reptiles. 2nd ed. CRC Press.

Johnson P. T. J., D. R. Sutherland, J. Kinsella, and K. B. Lunde. 2004. Review of the trematode genus Ribeiroia (Psilostomidae): ecology, life history and pathogenesis with special emphasis on the amphibian malformation problem. Advances in Parasitology 57: 191-253.

Kollros J. 1984. Limb regeneration in anuran tadpoles following repeated amputations. Journal of Experimental Zoology 232: 217-229.

Kupferberg S. J., A. Catenazzi, K. Lunde, A. J. Lind, and W. J. Palen. 2009. Parasitic copepod (Lernaea cyprinacea) outbreaks in foothill yellow-legged frogs (Rana boylii) linked to unusually warm summers and amphibian malformations in Northern California. Copeia 2009: 529-537.

Lacerda L. D., D. S. D. Araujo, and N. C. Maciel. 1993. Dry coastal ecosystems of the tropical Brazilian coast. Pp. 477-493 in E. van der Maarel (ed.), Dry coastal ecosystems: Africa, America, Asia, and Oceania. Amsterdam. Elsevier.

Lannoo M. 2008. The Collapse of Aquatic Ecosystems: Malformed Frogs. Berkeley. University of California Press. 288 pp.

Laurentino T. G., M. P. Pais, and G. M. Rosa. 2016. From a local observation to a European-wide phenomenon: Amphibian deformities at Serra da Estrela
Natural Park, Portugal. Basic and Applied Herpetology 30: 7-23.

Linzey D., J. Burroughs, L. Hudson, M. Marini, J. Robertson, J. Bacon, M. Nagarkatti, and P. Nagarkatti. 2003. Role of environmental pollutants on immune functions, parasitic infections and limb malformations in marine toads and whistling frogs from Bermuda. International Journal of Environmental Health Research 13: 125148.

Lunde K. B. and P. T. Johnson. 2012. A practical guide for the study of malformed amphibians and their causes. Journal of Herpetology 46: 429-441.

Mann R. M., R. V. Hyne, C. B. Choung, and S. P. Wilson. 2009. Amphibians and agricultural chemicals: Review of the risks in a complex environment. Environmental Pollution 157: 2903-2927.

Marco A., C. Quilchano, and A. R. Blaustein. 1999. Sensitivity to nitrate and nitrite in pond-breeding amphibians from the Pacific Northwest, USA. Environmental Toxicology and Chemistry 18: 2836-2839.

McDiarmid R. W. 1994. Preparing amphibians as scientific specimens. Pp. 289-297 in W. R. Heyer, M. A. Donnelly, R. W. McDiarmid, L. A. C. Hayek, and M. S. Foster (eds.), Measuring and Monitoring Biological Diversity: Standard Methods for Amphibians. Washington, D. C. Smithsonian Institution Press.

Mesquita D. O., G. C. Costa, and M. G. Zatz. 2004. Ecological aspects of the Casque-headed frog Aparasphenodon brunoi (Anura, Hylidae) in a Restinga habitat in southeastern Brazil. Phyllomedusa 3: 51-60.

Meteyer C. U. 2000. Field guide to malformations of frogs and toads with radiographic interpretations. Biological Scientific Reports USGS/BRD/BSR-2000-0005.

Meteyer C. U., I. K. Loeffler, J. F. Fallon, K. A. Converse, E. Green, J. C. Helgen, S. Kersten, R. Levey, L. EatonPoople, and J. G. Burkhart. 2000. Hind limb malformations in free-living northern leopard frogs (Rana pipiens) from Maine, Minnesota, and Vermont suggest multiple etiologies. Teratology Journal 62: 151-171.

Miles C. J. and R. J. Pfeuffer. 1997. Pesticides in canals of South Florida. Archives of Environmental Contamination and Toxicology 32: 337-345.

Monroy-Vilchis O., L. L. Parra-López, T. Beltrán-León, J. A. Lugo, A. Balderas, and M. M. Zarco-González. 2015. Morphological abnormalities in anurans from central Mexico: a case study. Herpetozoa 27: 115-121.

Moreira J. C., F. Peres, A. C. Simões, W. A. Pignati, E. C. Dores, S. N. Vieira, C. Strüssamann, and T. Mott. 2012. Contaminação de águas superficiais e de chuva por 
agrotóxicos em uma região do estado do Mato Grosso. Revista Ciência \& Saúde Coletiva 17: 1557-1568.

Murta-Fonseca R. A., M. Folly, L. F. Carmo, and A. Martins. 2020. Growing towards disparity: geometric morphometrics reveals sexual and allometric differences in Aparasphenodon brunoi (Anura: Hylidae: Lophyohylinae) head shape. Cuadernos de Herpetología 34: 05-15.

Ouellet M., J. Bonin, J. Rodrigue, J. DesGranges, and S. Lair. 1997. Hindlimb deformities (ectromelia, ectrodactyly) in free-living anurans from agricultural habitats. Journal of Wildlife Diseases 33: 95-104.

Pedroso-Santos F., P. R. Sanches, J. C. Sousa, and C. E. Costa-Campos. 2020. Anomalies in amphibians from the eastern Amazon region. Herpetological Bulletin 153: 22-25.

Peixoto O. L. 1995. Associação de anuros a bromeliáceas na Mata Atlântica. Revista da Universidade Rural 17: 7583.

Peltzer P., R. C. Lajmanovich, L. C. Sanchez, A. M. Attademo., C. M. Junges, C. L. Bionda, A. L. Martino, and A. Basso. 2011. Morphological abnormalities in amphibian populations from the mid-eastern region of Argentina. Herpetological Conservation and Biology 6: $432-442$.

Pimenta B. V. S., M. F. Napoli, and C. F. B. Haddad. 2009. A new species of casque-headed tree frog, genus Aparasphenodon Miranda-Ribeiro (Amphibia: Anura: Hylidae), from the Atlantic Rainforest of southern Bahia, Brazil. Zootaxa 2123: 4654.

Rajakaruna R. S., P. M. J. R. Piyatissa, U. A. Jayawardena, A. N. Navaratne, and P. H. Amerasinghe. 2008. Trematode infection induced malformations in the common hourglass treefrogs. Journal of Zoology 275: 89-95.

Ramírez-Jaramillo S. M. 2019. Primer reporte sobre la presencia de malformaciones en siete espécies de ranas (Amphibia, Anura) de bosque húmedo tropical en El Ecuador. Revista Latinoamericana de Herpetologia 2: $34-40$.

Rebouças R., H. R. Silva, and M. Solé. 2019. Malformations in insular and coastal populations of toads in Rio de Janeiro, Southeastern Brazil. South American Journal of Herpetology 14: 12-18.

Rocha C. F. D., F. H. Hatano, D. Vrcibradic, and M. Van Sluys. 2008. Frog species richness, composition and 口-diversity in coastal Brazilian restinga habitats. Brazilian Journal of Biology 68: 101-107.
Roelants K., D. J. Gower, M. Wilkinson, S. P. Loader, S. D. Biju, K. Guillaume, L. Moriau, and F. Bossuyt. 2007. Global patterns of diversification in the history of modern amphibians. Proceedings of the National Academy of Sciences of the United States of America 104: 887-892.

Santana M. M. S., P. R. Sanches, A. M. Oliveira-Souza, K. M. Okada-Aguiar, W. Almeida-Santos, and C. E. CostaCampos. 2020. Records of limb abnormalities in three anurans from eastern Amazon - Atelopus hoogmoedi, Allobates femoralis and Dendropsophus leucophyllatus. Herpetological Bulletin 151: 37-38.

Santos T. G., D. C. Rossa-Feres, and L. Cassati. 2007. Diversidade e distribuição espaço-temporal de anuros em região com pronunciada estação seca no sudeste do Brasil. Iheringia, Série Zoologia 9: 37-49.

Scarano F. R. 2002. Structure, function and floristic relationships of plant communities in stressful habitats marginal to the Brazilian Atlantic Rainforest. Annals of Botany 90: 517-524.

Schineider J. A. P. and R. L. Teixeira. 2001. Relacionamento entre anfíbios anuros e bromélias da Restinga de Regência, Linhares, Espírito Santo, Brasil. Iheringia, Série Zoologia 91: 41-48.

Schoff P. K., C. M. Johnson, A. M. Schotthoefer, J. E. Murphy, C. Lieske, R. A. Cole, L. B. Johnson, and V. R. Beasley. 2003. Prevalence of skeletal and eye malformations in frogs from north-central United States: estimations based on collections from randomly selected sites. Journal of Wildlife Diseases 39: 510521.

Scott J. R. and J. Norman. 2001. Técnicas estándar para inventários y monitoreos. Inventario completo de espécies. Pp. 1-349 in W. R. Heyer and M. A. Donnelly (eds.), Medición y Monitoreo de la Diversidad Biológica. Métodos Estandarizados para Anfíbios. Argentina. Comodoro Rivadavia. Editorial Universitaria de la Patagonia.

Shivaramaiah H. M., F. Sanchez-Bayo, J. Al-Rifai, and I. R. Kennedy. 2005. The fate of endosulfan in water. Journal of Environmental Science and Health Part B 40: 711720.

Silva D. P., I. A. M. Gomes, and M. A. L. Cruz. 2012. Vegetação de restinga: aspectos do impacto provocado pelo desenvolvimento sócio-econômico da região NorteFluminense e alternativas para sua valorização. InterSciencePlace 1: 71-83.

Simon E., M. Puky, M. Braun, and Tóthmérész B. 2011. Frogs and toads as biological indicators in environmental assessment. Pp. 141-150 in J. L. Murray (ed.), 
Frogs: Biology, Ecology and Uses. New York. Nova Science Publishers Inc.

Spadotto C. A., M. A. F. Gomes, L. C. Luchini, and M. M. Andrea. 2004. Monitoramento do risco ambiental de agrotóxicos: princípios e recomendações. Jaguariúna: Embrapa Meio Ambiente (Documentos 42): 1-29.

Stocum D. L. 2000. Frog limb deformities: an 'eco-devo' riddle wrapped in multiple hypotheses surrounded by insufficient data. Teratology 62: 147-150.

Stuart S. N., J. S. Chanson, N. A. Cox, B. E. Young, A. S. L. Rodrigues, D. L. Fischman, and R. W. Waller. 2004. Status and trends of amphibian declines and extinctions worldwide. Science 306: 1783-1786.

Svinin A. O., I. V. Bashinskiy, S. N. Litvinchuk, O. A. Ermakov, A. Y. Ivanov, L. A. Neymark, A. A. Vedernikov, V. V. Osipov, G. P. Drobot, and A. Dubois. 2020. Strigea robusta causes polydactyly and severe forms of Rostand's anomaly P in water frogs. Parasites \& Vectors 13: 381.

Teixeira R. L., J. A. P. Schineider, and G. I. Almeida. 2002. The occurrence of amphibians in bromeliads from southeastern Brazilian resting habitat, with special reference to Aparasphenodon brunoi (Anura, Hylidae). Brazilian Journal of Biology 62: 263-268.

Thigpen C. S., D. Beard, and S. E. Trauth. 2014. Toad (Anura: Bufonidae) limb abnormalities from an aquatic site in Scott, Pulaski County, Arkansas. Journal of the Arkansas Academy of Sciences 68: 106-109.
Toledo L. F. and R. S. Ribeiro. 2009. The Archipelago of Fernando de Noronha: an intriguing malformed toad hotspot in South America. EcoHealth 6: 351-357.

Trueb L. 1970. Evolutionary relationships of casque-headed tree frogs with co-ossified skulls (family Hylidae). University of Kansas Publications, Museum of Natural History 549: 1-716.

Valdespino C., A. I. Huerta-Peña, A. Pérez-Pacheco, and J. R. V. Osten. 2015. Persistent organochlorine pesticides in two Hylidae species from the La Antigua Watershed, Veracruz, Mexico. Bulletin of Environmental Contamination and Toxicology 94: 17-22.

Vázquez-Corzas F. G., A. Sandoval-Comte, P. HernándezLópez, S. Ibáñez-Bernal, and E. Pineda. 2018. First records of parasitoidism by Sarcophagidae flies (Diptera) on three amphibian species in Mexico. Journal of Natural History 52: 35-36.

Vershinin V. L. 2015. Osnovy metodologii $i$ metody issledovanija anomalii $i$ patologii amphibii. $1^{\text {st }}$ ed. Ekaterinburg (Uralskii Federalnyi Universitet), Publishing house Ural. 80pp.

Wogel H., L. N. Weber, and P. A. Abrunhosa. 2006. The tadpole of the casque-headed frog, Aparasphenodon brunoi Miranda-Ribeiro (Anura: Hylidae). South American Journal of Herpetology 1: 54-60.

Zaks, M. M. 2008. On the morphological anomalies of green frogs (Rana ridibunda, $R$. lessonae) in Penza-city (Russia). Izv. Penz. gos. Pedagog. univ. im.i V.G. Belinskogo 10: 63-65.

Editor: Vanessa K. Verdade 